\title{
Structural Insights into Substrate Recognition and Processing by the 20S Proteasome
}

\author{
Indrajit Sahu *(1) and Michael H. Glickman * \\ Faculty of Biology, Technion-Israel Institute of Technology, 32000 Haifa, Israel \\ * Correspondence: indrajitsahu@technion.ac.il (I.S.); glickman@technion.ac.il (M.H.G.); \\ Tel.: +972-0586747499 (I.S.); +972-4-829-4552 (M.H.G.)
}

check for

updates

Citation: Sahu, I.; Glickman, M.H Structural Insights into Substrate Recognition and Processing by the 20S Proteasome. Biomolecules 2021, 11, 148. https://doi.org/10.3390/ biom 11020148

Academic Editor: Paolo Cascio

Received: 3 January 2021

Accepted: 21 January 2021

Published: 24 January 2021

Publisher's Note: MDPI stays neutral with regard to jurisdictional claims in published maps and institutional affiliations.

Copyright: (C) 2021 by the authors. Licensee MDPI, Basel, Switzerland. This article is an open access article distributed under the terms and conditions of the Creative Commons Attribution (CC BY) license (https:// creativecommons.org/licenses/by/ $4.0 /)$.

\begin{abstract}
Four decades of proteasome research have yielded extensive information on ubiquitindependent proteolysis. The archetype of proteasomes is a $20 \mathrm{~S}$ barrel-shaped complex that does not rely on ubiquitin as a degradation signal but can degrade substrates with a considerable unstructured stretch. Since roughly half of all proteasomes in most eukaryotic cells are free $20 S$ complexes, ubiquitin-independent protein degradation may coexist with ubiquitin-dependent degradation by the highly regulated $26 \mathrm{~S}$ proteasome. This article reviews recent advances in our understanding of the biochemical and structural features that underlie the proteolytic mechanism of 205 proteasomes. The two outer $\alpha$-rings of $20 S$ proteasomes provide a number of potential docking sites for loosely folded polypeptides. The binding of a substrate can induce asymmetric conformational changes, trigger gate opening, and initiate its own degradation through a protease-driven translocation mechanism. Consequently, the substrate translocates through two additional narrow apertures augmented by the $\beta$-catalytic active sites. The overall pulling force through the two annuli results in a protease-like unfolding of the substrate and subsequent proteolysis in the catalytic chamber. Although both proteasomes contain identical $\beta$-catalytic active sites, the differential translocation mechanisms yield distinct peptide products. Nonoverlapping substrate repertoires and product outcomes rationalize cohabitation of both proteasome complexes in cells.
\end{abstract}

Keywords: 20S proteasome; protein degradation; intrinsically disordered proteins; enzyme functional cycle; peptides; peptidome; proteome; oxidative stress

\section{Introduction}

Two major species of proteasome coexist in most cells: the $20 \mathrm{~S}$ proteasome as a standalone complex, and the 20S complex as a core particle that is associated with regulatory particles or activators [1-3]. The $20 S$ is a self-compartmentalized protease complex [4] that carefully selects substrates having substantiate disordered or misfolded stretches [5-7] and proteolyses them once they enter into the inner chamber. Under in vitro conditions without any activators or associated unfoldase activities, the 205 proteasome proteolyses unstructured proteins or extended polypeptides [8-14]. Interestingly, archaea and some bacteria have $20 \mathrm{~S}$ proteasomes alongside other ATP-dependent proteases, which supports the idea of the 20S complex being a primordial protein-degrading machine [15]. Usually, these simple $20 S$ proteasomes are made up of 14 copies of $\alpha$ and $\beta$ subunits each [16,17], intermittently aided by a loosely associated homomeric ring of ATPases [15,18,19]. All $\beta$ subunits in archaeal proteasomes are catalytically active proteases arranged in two concerted rings around an enclosed catalytic chamber, with the $14 \alpha$ subunits forming two outer rings through which substrate enters. In contrast to archaea, $20 \mathrm{~S}$ proteasomes in eukaryotes display greater complexity, with seven different types of $\alpha$ and $\beta$ subunits each, stacked in a four-ringed 20S complex. The symmetry mismatch between seven different $\alpha$ subunits in each outer ring enables a gating mechanism, which provides a regulatory system for substrate entry [20-23]. Regarding the $\beta$ subunits, out of seven only three retain proteolytic activity in eukaryotes influencing the peptide product outcome [24]. 
In eukaryotic cells, $20 \mathrm{~S}$ proteasomes function independently and act directly on disordered proteins [25-29] or oxidized proteins $[6,14,26,30,31]$, substantiating its potential role as a stand-alone protease. Nevertheless, its activity is augmented by various activators that attach to the $20 S$ proteasome, aiding substrate recruitment and processing, thereby broadening its substrate repertoire. The $19 \mathrm{~S}$ regulatory particle (RP) is the major activator that enables the $20 \mathrm{~S}$ proteasome to degrade virtually any protein tagged with the small protein modifier ubiquitin [32,33]. Either one or two 19S RPs can attach to a single $20 \mathrm{~S}$ catalytic core particle (CP) to form the singly capped 26S, or the doubly capped 30S, respectively (Figure 1) [34]. We refer readers to a number of recent reviews on 26S proteasomes [35-40]. Additional, simpler, non-ATPase activators can also associate with 20S CPs (e.g., PA200, PA28; $[3,18,41-48])$, although their mode of action in substrate degradation is vague and will not be detailed in this review.

\section{Cellular distribution of Proteasome complexes}

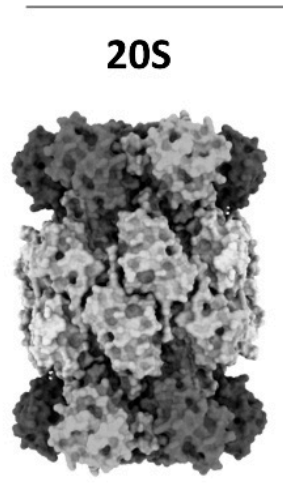

45-75\%

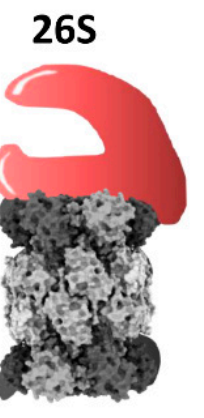

$15-25 \%$

\section{$30 S$}

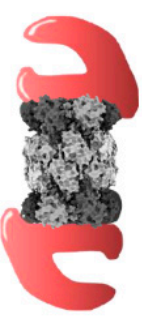

$5-15 \%$

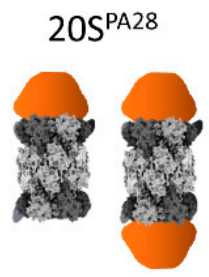

$2-10 \%$

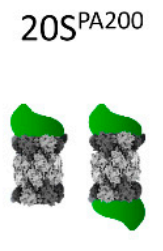

$1-2 \%$
Hybrid

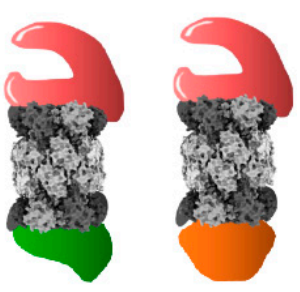

?

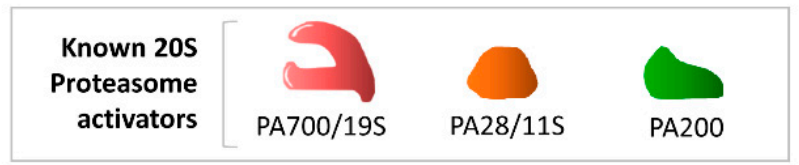

Figure 1. Cellular distribution of different proteasome complexes in mammalian cells. The $20 \mathrm{~S}$ model figure was generated by ChimeraX using the $20 \mathrm{~S}$ cryo-EM structure [49]. The average percentages are calculated based on published reports [3]. The size of each proteasome species corresponds to the average value of the range denoted to visually illustrate their relative abundance in cell lines that have been quantified.

Although the 20S complex as a core particle is an integral part of all species of larger complex proteasomes in eukaryotes $[10,50]$, it is quite abundant as a free complex in many cell types, estimated in some studies at $~ 50 \%$ of all proteasome species [3] (Figure 1). It has been suggested that free $20 \mathrm{~S}$ complexes may be proteasome assembly intermediates, $26 \mathrm{~S}$ breakdown products (due to disassembly), or stand-alone proteolytic enzymes $[1,5-7,14,21,51-57]$. Since the ratio of $20 \mathrm{~S}$ to $26 \mathrm{~S}$ proteasome varies across different cellular conditions, a dynamic equilibrium between the two species may be part of an adaptive response to cellular needs [58]. Although its functionality as an independently active enzyme under cellular conditions is a matter of debate, recent advances have highlighted a role for $20 \mathrm{~S}$ as a functional proteasome in cells. Various reports suggest a role of $20 \mathrm{~S}$ as an emergency proteasome under cellular stress, for example oxidative stress or hypoxic stress [25,49,56,59-61], to provide survival benefits under proteotoxicity [26].

Any physiological condition that demands an alteration to the proteome or impairs protein function requires enhanced capacity to remove the unnecessary load. Common stress conditions such as oxidation, temperature, ionization or toxins directly damage proteins but also inevitably affect the ubiquitin-proteasome machinery. Indeed these stress conditions can lead to 26S accumulation in storage granules [62-64], its disassembly [1,2,65], 
ubiquitination [66], or proteophagy [67-69]. Nevertheless, 20S CPs are relatively resistant to oxidation damage compared to $26 \mathrm{~S}$ proteasomes and persist as a stable complex under such conditions $[57,70]$. Fine-tuning the proteolytic machinery by altering the proteasome species ratio may be a strategy which cells utilize to survive under proteotocixity. For instance, ischemic-related hypoxia, a pathological condition of heart failure, is characterized by oxidative stress [71], and disassembly of the $26 \mathrm{~S}$ proteasome [72,73]. While many studies have focused specifically on the decline of the $26 \mathrm{~S}$ proteasome in acute conditions such in heart failure and during aging in general, residual $20 S$ proteasome activity may contribute to the removal of misfolded or damaged proteins under a variety of stress conditions. Hence, it is most likely that $20 \mathrm{~S}$ proteasomes play a role under stress conditions, yet how they serve to alleviate proteotoxicity is unclear. We refer readers to a number of recent reviews that highlight the participation of the $20 \mathrm{~S}$ proteasomes in biological regulation or in the potential substrate repertoire $[5,7,74,75]$.

Several structural studies on $20 \mathrm{~S}$ proteasomes by crystallography, cryo-EM or atomic force microscopy have detailed the arrangements of all the 28 subunits to their atomic resolution (Figure 2) [76] and modes of substrate association [77-79]. Although 20S proteasomes can degrade proteins, details of their functional cycle and associated conformational changes are still obscure. In this review we correlate the structural information with biochemical knowledge to describe how the structural features of $20 \mathrm{~S}$ proteasomes are competent to recognize and degrade their preferred substrates. The following review will focus on the aspects of $20 \mathrm{~S}$ proteasome structure-function correlation based on recent advancement of knowledge and provide predictive models for its degradation functional cycle.

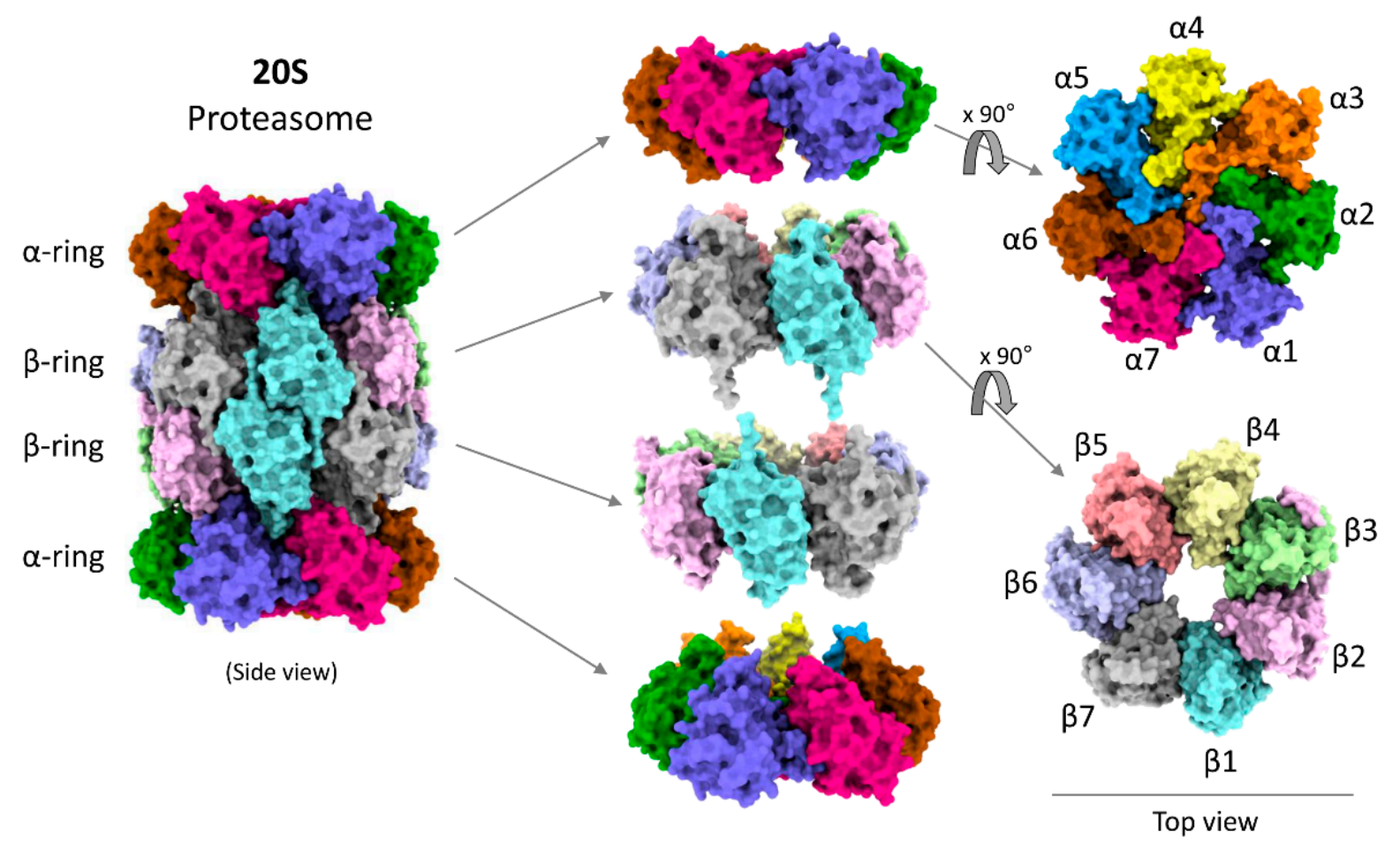

Figure 2. Model structure of human 20S proteasome. Model figures were generated by ChimeraX using the 20S cryo-EM structure [49].

\section{Substrate Degradation Signals for 20S Proteasomes}

Preferred substrates for degradation by $20 \mathrm{~S}$ proteasomes are unstructured, unfolded or misfolded proteins. Various studies have addressed the ability of $20 \mathrm{~S}$ proteasomes to degrade proteins of this category both in in vitro and in vivo conditions $[9,25,26,28,49,59,80-83]$. Hence, the targeting signal to $20 \mathrm{~S}$ proteasomes is considered to be an unstructured polypeptide segment on a substrate. Many proteins possess intrinsic unstructured segments, but often 
the segments are either concealed within the protein itself [84], or protected/stabilized by binding partners or chaperones [85]. Once exposed, the segment could target the entire protein for degradation. It has been well reported that upon oxidation various proteins (e.g., $\alpha$-Lactalbumin) become substrates of the $20 \mathrm{~S}$ proteasome under in vitro conditions [78]. Under hypoxia or oxidative stress conditions oxidized cellular proteins are readily degraded by $20 S$ proteasomes [61]. Since oxidative damage can lead to increase disorderedness and decrease protein stability, it could affect the structure of proteins by exposing the buried or intrinsic unstructured segments that might act as signals for $20 \mathrm{~S}$ proteasome recognition and proteolysis. Furthermore, 20S proteasomal S-glutathionylation is a relevant adaptive response to oxidative stress that is capable of sensing the intracellular redox environment, leading to the removal of oxidized proteins via a process that is not dependent upon ubiquitylation and ATP consumption [86,87]. Hence, cellular oxidative conditions regulate $20 \mathrm{~S}$ proteasome activity and specificity by modifying both proteins and proteasomes.

Proteins with a substantial measure of disorderedness have been named intrinsically disordered proteins (IDPs), and a role for 20S proteasomes in degrading them has been proposed [59]. Nevertheless, a short unstructured segment does not imply that the $20 \mathrm{~S}$ proteasome is the primary protease for their removal, as most IDPs also undergo ubiquitination which leads to degradation by $26 \mathrm{~S}$ proteasomes [88]. Since ubiquitinated substrates are preferentially degraded by $26 \mathrm{~S}$ proteasomes, it is reasonable to assume that the non-ubiquitinated IDPs would be degraded by $20 \mathrm{~S}$ proteasomes. Indeed, in certain in vitro experiments, the rate of proteolysis of non-ubiquitinated disordered proteins by $20 \mathrm{~S}$ proteasomes was faster than by $26 \mathrm{~S}$ proteasomes [49]. This could be explained by the hindrances to substrate processing and translocation found in the resting state of $26 \mathrm{~S}$ proteasomes [39,40], nevertheless, it remains in question how disordered proteins can be targeted to 20S proteasomes and what activates these proteases for proteolysis. Apparently, certain features in disordered segments can engage with the 20S $\alpha$-ring (Figure 2) and in this manner, some substrates can promote gating of the $20 \mathrm{~S}$ proteasome to facilitate their own degradation [11]. Lacking ubiquitin-binding domains or ATPase subunits, $20 \mathrm{~S}$ proteasome activity is adversely affected by the presence of globular domains within a partially unstructured polypeptide, or by conjugation of a substrate to the tightly folded ubiquitin. A recent study demonstrated that addition of ubiquitin units to a model disordered substrate, CyclinB1, slowed down the overall degradation rate of CyclinB1 by free $20 \mathrm{~S}$ proteasomes [49]. Under such circumstances, 20S proteasomes either release the globular domain [11] or degrade the globular domain along with the unstructured portion of the substrate [49]. Despite its preference towards disordered proteins, detailed knowledge on how an unstructured polypeptide stretch is recognized as a signal by $20 \mathrm{~S}$ proteasomes and what triggers a functional cycle is largely obscured. Further structural studies with substrate are necessary to address this issue.

\section{Structural Precision of 20S Proteasomes for Substrate Degradation}

Structurally, the $20 \mathrm{~S}$ proteasome is a hollow cylindrical barrel consisting of four ringstwo peripheral $\alpha$-rings and two central $\beta$-rings (Figure 2). Each $\alpha$-or $\beta$-ring consists of seven homologous subunits $(\alpha 1,2,3,4,5,6,7$ or $\beta 1,2,3,4,5,6,7)$ positioned such that the C-terminus of each subunit faces outwards, while the N-terminus faces inwards. The upper and the lower $\alpha \beta$-rings (half-20S) are arranged in a reverse order: all four rings are aligned at $\alpha 1 / \beta 1 / \beta 1 / \alpha 1$ subunits, with one half-20S running clockwise from subunit 1 to 7 whereas the other half-20S is arranged counterclockwise, providing an overall $\mathrm{C} 2$ symmetry to the $20 \mathrm{~S}$ barrel (Figure $3 \mathrm{~A}$ ). The inner cavity of the $20 \mathrm{~S}$ proteasome is divided into a central catalytic chamber lined by all the fourteen $\beta$-subunits, and two antechambers enclosed by the $\alpha$-subunits (Figure 3B). Although the function of the $\beta$-catalytic subunits in the catalytic chamber are very well defined, the contribution of the two antechambers towards $20 \mathrm{~S}$ proteasome function is not as clear [89-91]. An antechamber is not a strict requirement for 
a self-compartmentalized protease, since the proteasome-related prokaryotic HslV contains only two $\beta$-type rings enclosing a sole catalytic chamber [92].

A

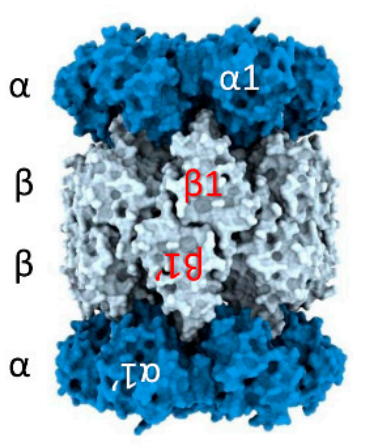

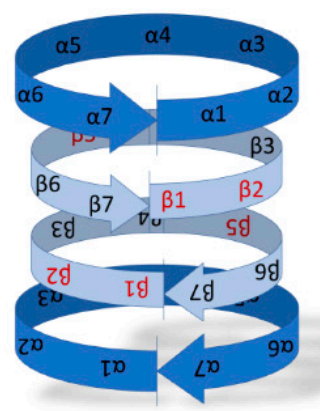

B

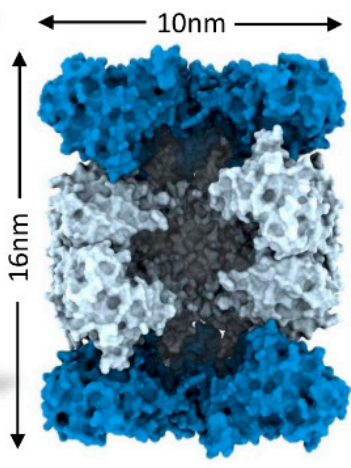

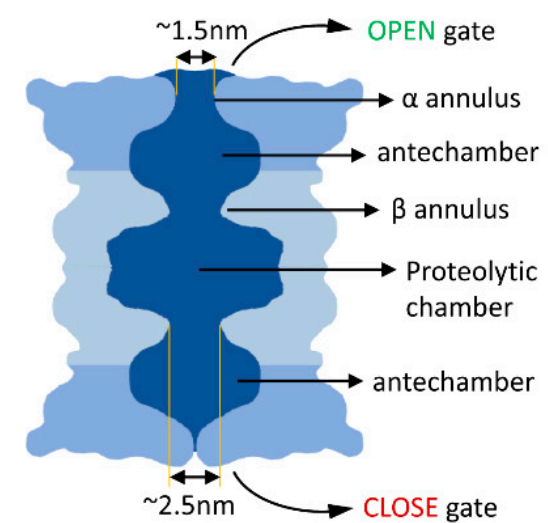

D C-terminus $\mathrm{N}$-terminus $\mathrm{K}$-pockets

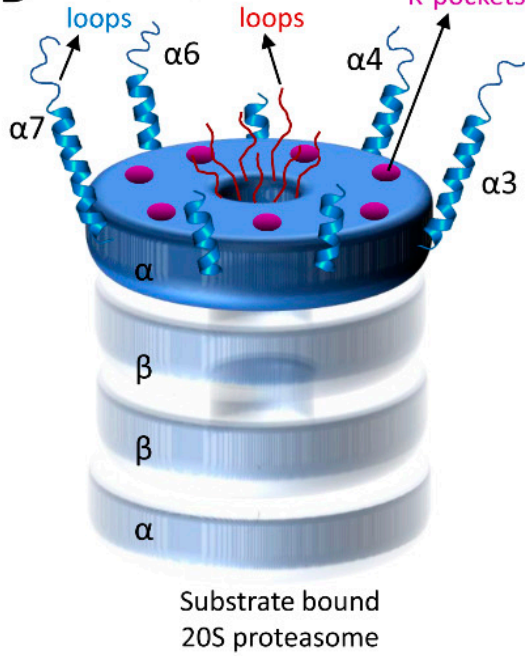

E

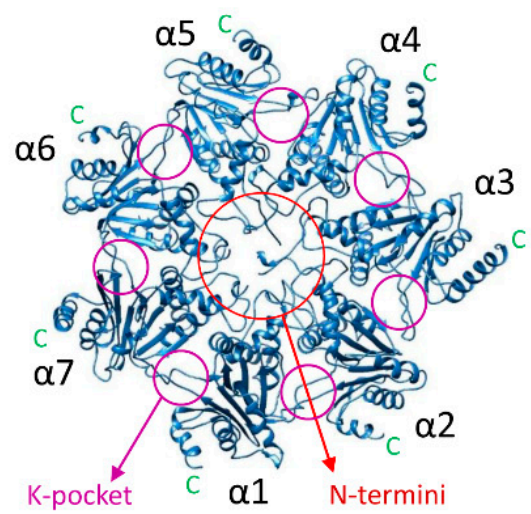

Resting 20S proteasome

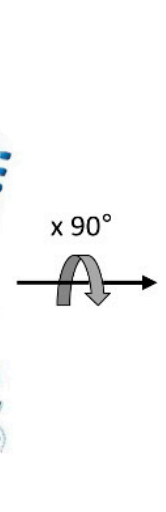

$\beta$

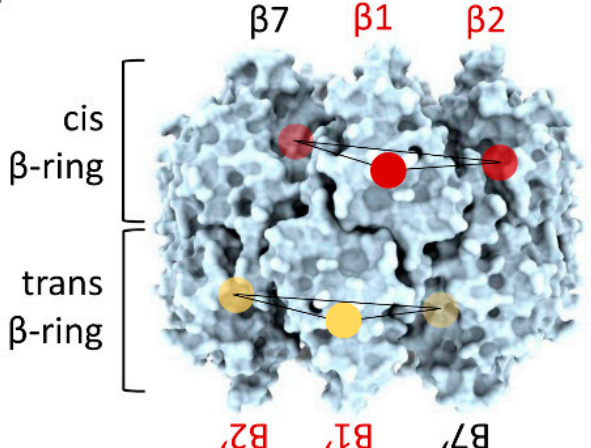

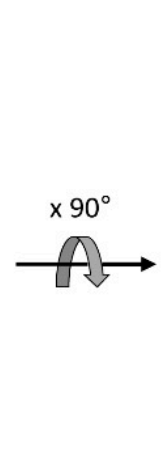

$\beta 4$

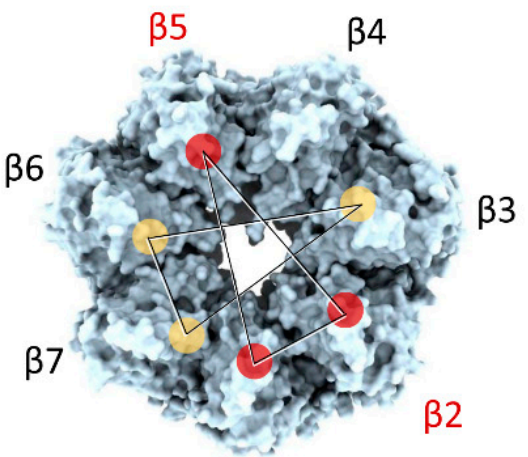

$\beta 1$

Figure 3. Structural precision of 20S proteasomes for substrate degradation. (A) The C2-symmetry of the 20S proteasome complex highlighting $\alpha$-rings and the $\beta$-rings. (B) A slice through the interior of the $20 \mathrm{~S}$ proteasome highlighting the proteolytic chamber separated from the two antechambers by $\beta$-annulus. (C) Central location of $\alpha$-subunit $N$-termini and the peripheral positions of $\alpha$-subunit C-termini in resting 20S proteasomes. (D) A cartoon representation of the $\mathrm{N}$-termini, C-termini and K-pockets on the $\alpha$-ring of substrate-engaged 20S proteasomes. (E) Spatial distribution of the $\beta$-subunit catalytic sites ( $\beta 1, \beta 2$ and $\beta 5$ ) in cis- and trans- $\beta$-rings. The model figures of $20 S$ complexes were generated by ChimeraX using the 20S cryo-EM structure [49].

Access to the inner cavity of the $20 \mathrm{~S}$ proteasome is through a channel in the center of the $\alpha$-rings. In the resting "latent" state, the channel is sealed by the intertwining extended 
$\mathrm{N}$-termini of all seven $\alpha$-subunits [20,22]. Upon binding of a regulator (19S/ PA200/ PA28), these N-termini shift, opening or closing depending on the proteasome functional state and hence this region is called the "gate" of the 20S CP [93-96]. However, even in absence of any regulator, $20 \mathrm{~S}$ proteasomes can still degrade certain substrates-occasionally faster than $26 \mathrm{~S}$ proteasomes-implying that the gate can also be opened by substrates with specific features $[11,49,97])$. At this time, it is unclear how substrates access free $20 \mathrm{~S}$ proteasomes; however, structural features of the $\alpha$-ring provide possible substrate-binding interfaces. For instance, in the substrate translocating state of $26 \mathrm{~S}$ proteasomes, disorderedness is apparent in the extended N-termini of the $\alpha$-subunits [98] implying that even in the 26S, the gate into the core particle is not merely "open" but rather the $\alpha$-subunit $\mathrm{N}$-termini retain the potential to interact with the substrate as it slides through. By analogy, substrates may interact directly with these $\mathrm{N}$-termini in free $20 \mathrm{~S}$ proteasomes, facilitating disorderedness and gate opening (Figure 3C).

C-terminal helixes at each of the seven $\alpha$-subunits provide another potential medium for substrate association with $20 \mathrm{~S}$ proteasomes. Each $\alpha$-subunit terminates in an extended helix-loop motif projecting outward from the $20 \mathrm{~S}$ proteasome surface (Figure 3D). The lengths of these C-termini vary from 15 to 40 aa residues, the longest of which ( $>30 \mathrm{aa}$ ) belong to $\alpha 3, \alpha 4, \alpha 6$ and $\alpha 7$. Since these termini are not completely resolved in CryoEM images or in crystal structures of $20 \mathrm{~S}$ proteasomes, they are most likely flexible in nature. Such long flexible helix-loops provide putative binding interfaces for substrates with unstructured stretches. Reportedly, the C-terminus of the $\alpha 7$ subunit interacts with retinoblastoma $(\mathrm{Rb})$ protein, $\mathrm{p} 21$, and $\mathrm{Cdc} 25 \mathrm{C}$ proteins and facilitates their degradation in a ubiquitin-independent manner $[83,99,100]$. A third potential module for substrate interactions with $20 \mathrm{~S}$ proteasomes are the lysine-pockets (K-pockets) on the outer $\alpha$-surface (Figure 3C,D). Seven lysine-pockets are documented to bind a HbYX motif at the C-termini of most activators of $20 \mathrm{~S}$ CPs, triggering gate opening [94,96,101-105]. Short peptides bearing such $\mathrm{HbYX}$ motifs at their C-terminus are reported for their ability to induce 20S CP gate opening, and so are some proteins or peptides that do not strictly adhere to the $\mathrm{HbYX}$ rule $[106,107]$. We propose that this mode of regulation could be utilized by substrate-proteins bearing similar motifs inserting into lysine-pockets on 20S CP surface to trigger gate opening and enhance their own degradation. Furthermore, 20S gating can be regulated by post-translation modification on the proteasome subunit itself. It has been reported that, under oxidative stress S-glutathionization on specific cysteine residues (Cys76 and C221) of the $\alpha 5$ subunit modulates 20S gate opening for proteolysis of oxidized proteins $[86,87,108]$.

After entering the gated channel into the $20 \mathrm{~S}$ proteasome, substrates first traverse an antechamber defined by the $\alpha$-subunits and only then enter through a $\sim 2.5 \mathrm{~nm}$ diameter aperture defined by the $\beta$-annulus into the central proteolytic chamber (Figure 3B). The catalytic chamber is a central oval-shaped cavity about $5-6 \mathrm{~nm}$ wide. Notably, of all fourteen $\beta$ subunits, only six subunits in eukaryotic $20 \mathrm{~S}$ proteasomes have the active Threonine nucleophile at the $\mathrm{N}$-terminus (by post-translational $\mathrm{N}$-terminal trimming) $[90,109]$. The catalytic sites of the enzymatic $\beta$-subunits $(\beta 1, \beta 2$ and $\beta 5)$ face towards the center of the cavity (Figure $3 \mathrm{E}$ ). Between them, they can cleave most peptide bonds since the $\beta 1$ enzyme shows caspase-like (post acidic amino acid), $\beta 2$ displays trypsin-like (post-basic), and $\beta 5$ exhibits chymotrypsin-like (post-hydrophobic) specificities $[89,110,111]$. Since the two $\beta$-rings stack over the $\beta 1-\beta 1^{\prime}$ pair and run in opposite directions to each other, the two other catalytic subunit pairs, $\beta 2-\beta 2^{\prime}$ and $\beta 5-\beta 5^{\prime}$, are not located one over the other (Figure $3 \mathrm{E}$ ). The dispersed arrangement of few active subunits in the double $\beta$-ring (6 out of 14) leaves a gap at the $\beta 4$ subunits where no in proteolytic sites are present. In contrast to primordial 20S proteasomes where all $14 \beta$-subunits are catalytically active, it is possible that this "proteolytic gap" affords for partial cleavage of the substrates and generation of slightly longer peptide products that retain sequence information for downstream signaling pathways (see heading 5). 


\section{The Functional Cycle of 20S Proteasomes}

$20 \mathrm{~S}$ proteasome structure has been studied in great detail at atomic resolution and extensive information has been amassed regarding its assembly, catalytic mechanism and modes of activation $[24,112,113]$. In this section we will concisely discuss substrate-induced conformational changes to $20 \mathrm{~S}$ proteasome structures and attempt to ascribe hypothetical functional states during substrate degradation. Cross-referencing available biochemical and structural studies, we propose the following functional states: (1) substrate accepting state, (2) substrate binding state, and (3) substrate processing state.

\subsection{Substrate Accepting State (SA)}

Under most in vitro conditions, the $20 \mathrm{~S}$ proteasome is found in a latent form with a closed gate conformation $[20,79,102,104]$. The $\mathrm{N}$-terminal loops of the $\alpha$-subunits extend into the center of the $\alpha$-ring coming into close contact to form a plug with a few termini curving upwards at the epicenter (Figure $3 \mathrm{C}$ ). The close gate hinders random entry of polypeptides, even of small tetra-peptides (such as the commonly used LLVY-AMC substrate), hence it is often referred to as the latent 20S CP. In its latent form, a free $20 \mathrm{~S}$ proteasome is ready to accept potential substrates with loosely folded stretches; however, how these substrates are recognized by the $20 S$ proteasome is largely obscure. As mentioned above, in the substrate accepting state, a few structural features on the $\alpha$-rings may interact with potential substrates: (a) the flexible $\mathrm{N}$-terminal loops that form the gate, (b) through the extended C-terminal loops, or (c) through the lysine-pockets (Figure 3D). These multiple modes of substrate association probably facilitate the gate opening and lead to further conformational changes that increase affinity of binding and engagement of the substrate.

\subsection{Substrate Binding State (SB)}

The first direct evidence that substrate enters at the center of the $\alpha$-ring was obtained by negative staining EM of stalled archaeal $20 \mathrm{~S}$ proteasomes [78]. Interestingly, archaeal $20 \mathrm{~S}$ proteasomes can engage the substrate at both sides of the complex simultaneously $[78,114]$. However, more recently, an unstructured substrate (CyclinB1) was shown to trigger gate opening in one of the $\alpha$-rings of the free human 20S proteasome and induce conformational changes to half of the $20 \mathrm{~S}$ barrel (Figure 4A,B) [49]. This result is in line with another recent demonstration that attachment of simple regulatory particles to archaeal $20 \mathrm{~S}$ proteasomes introduced extensive allosteric changes extending from one outer $\alpha$-ring to the catalytic sites at the center but not to the other half of the 20S barrel [115]. Furthermore, in cryo-EM images of substrate-engaged $26 \mathrm{~S}$ proteasomes, the distal surface of the $20 \mathrm{~S} \mathrm{CP}$ remained closed $[98,116]$. Together, these observations suggest that human proteasomes can engage the substrate and trigger gate opening at one side, resulting in an asymmetric conformational change of the $20 \mathrm{~S}$ barrel (Figure 4A).

Just below the gate into the proteolytic channel of the $20 \mathrm{~S}$ proteasome there is a relatively stable narrow aperture lined by loops from all the $\alpha$-subunits; the $\alpha$-annulus. Interaction with these loops most likely provides substrate engagement to ensure entry into the antechamber (Figure $4 \mathrm{C})$. Moreover, the aperture diameter $(\sim 1.5 \mathrm{~nm})$ is compatible with a loosely folded polypeptide for interaction as it translocates through. A study by the Thomas and DeMartino groups reported that two extended polypeptides can cotranslocate through the same gate simultaneously; however, the fused globular GFP domain was released without getting degraded [11]. Further evidence that more than two polypeptides can enter simultaneously through the same gate and annulus stemmed from a recent study demonstrating that free $20 \mathrm{~S}$ can proteolyse a Lysine48-linked tetraUb chain when attached to an unstructured substrate-CyclinB1 [49]. In the absence of any unfoldase/ATPase modulator, how the $20 \mathrm{~S}$ proteasome upholds the ability to unfold and translocate a tightly folded protein such as ubiquitin remains to be elucidated. Given these biochemical observations, it would be interesting to investigate whether the $20 \mathrm{~S}$ proteasome maintains these abilities in cells where it may associate with unfoldases/ATPase modulators (other than 
19S), non ATPases activators or chaperons to aid degradation of small globular domains or proteins.

A

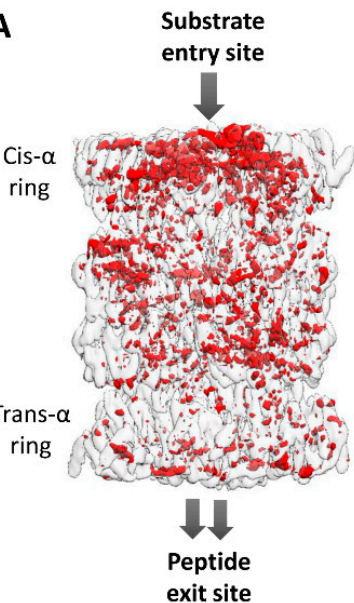

C

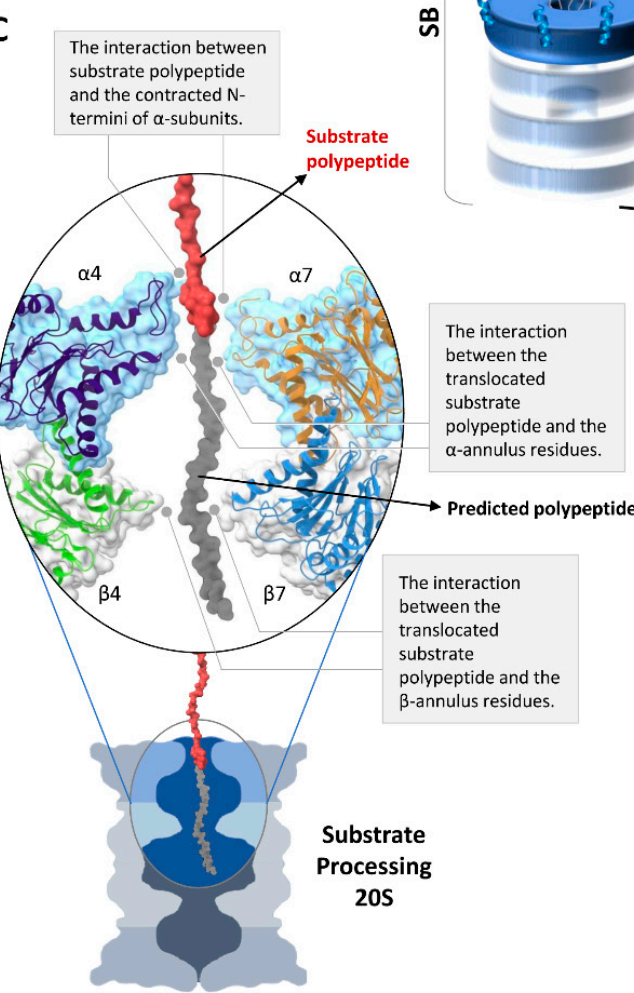

B

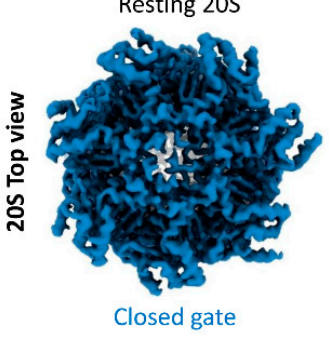

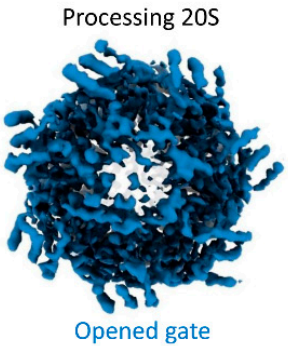

D

Binding to

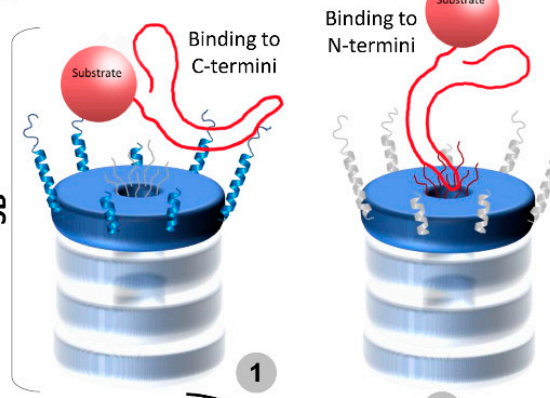

13

3

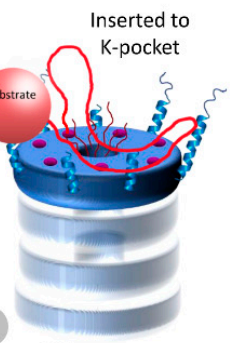

2

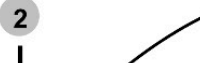

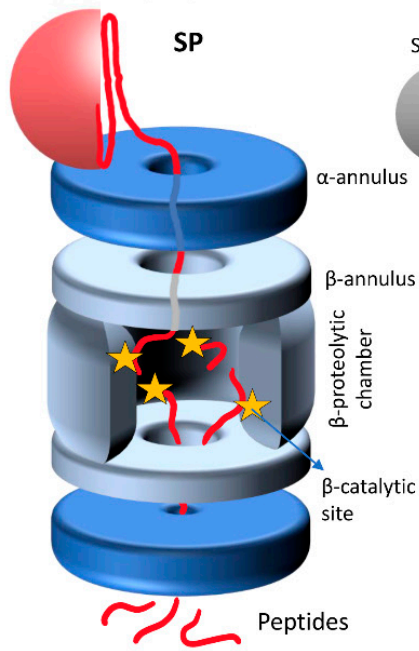

Substrate

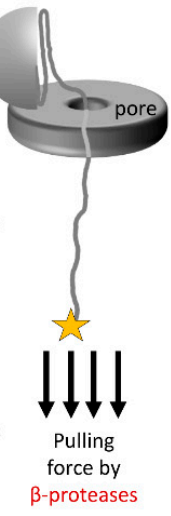

Figure 4. Structural conformational changes during substrate processing and functional model of the 20S proteasome. (A) A differential map rendering the asymmetric pattern between the trans- and cis- $\alpha$-rings of substrate-processing human $20 S$ proteasomes [49]. (B) The top view electron density map exposing the cis $\alpha$-ring of resting $20 \mathrm{~S}$ proteasome vs. substrate processing $20 \mathrm{~S}$ proteasome [49]. (C) Potential interactions of a substrate polypeptide with the contracted N-termini of $\alpha$-subunits, $\alpha$-annulus residues, and $\beta$-annulus residues during substrate processing state. The surface and embedded cartoon representation of $\alpha 4 / 7$ - and $\beta 4 / 7$ along with the substrate polypeptide (in red) image was generated using the model of substrate-bound human $26 \mathrm{~S}$ proteasomes (PDB: $6 \mathrm{msk}$ ). A putative extension of the substrate polypeptide is colored grey for illustration purposes. (D) A model mechanism of substrate processing by $20 \mathrm{~S}$ proteasomes. In substrate accepting state, we propose that the unstructured portion of the substrate would recognize and interact either with (1) the protruding C-termini of $\alpha$-subunits, or with (2) the long N-terminal loops of $\alpha$-subunits, or (3) may insert into K-pockets of $\alpha$-subunits. The pulling force of $\beta$-proteases aids unfolding of the remainder of the substrate against the $\alpha$-and $\beta$-annulus (aperture) by a ratchet mechanism. 


\subsection{Substrate Processing State (SP)}

After binding at the $\alpha$-subunits, the substrate must translocate through the antechamber into the catalytic chamber for proteolysis. In order to do so, the substrate polypeptide has to enter through yet another aperture of the $\beta$-annulus. Though its diameter $(\sim 2 \mathrm{~nm})$ is comparatively wider than $\alpha$-annulus aperture, it might provide yet another interaction/contact point to the substrate polypeptide for translocation towards the catalytic chamber (Figure $4 \mathrm{C}$ ). Entrapment by the $\beta$-subunit active sites provide a pulling force for continuous inward movement of the substrate polypeptide. A conceptual mechanism for "protease-like unfolding" by the group of Zhou has demonstrated that a polypeptide pulled through a narrow aperture in a wall leads to one-by-one breaking of hydrogen bonds, bypassing the initial force barrier required to overcome the tertiary structure of a globular protein [117]. Such a ratchet mechanism by a protease through a narrow aperture requires lower energy of unfolding than that of an energy-dependent ATPase. Specifically, pulling ubiquitin by its $\mathrm{C}$-terminus against a nanoscale aperture yielded a mechanical force that unfolded the native conformation. Likewise, it is possible that ubiquitin conjugated at its $C$-terminus to an unfolded polypeptide long enough to reach the $\beta$-subunit protease sites can be unfolded by free 20S proteasomes as it is pulled through the $\alpha$-ring aperture. In absence of any unfoldase, 20S proteasomes may follow a similar mechanism of substrate unfolding by a $\beta$-enzyme pulling action through two such narrow apertures $(\alpha$-and $\beta$-annulus) for efficient proteolysis (Figure 4D). Attaching an antechamber to a catalytic chamber and requiring substrates to traverse a number of narrow apertures provides the contact points for 20S-directed proteolysis. Nevertheless, for the execution of substrate translocation sufficient evidence from structural data and the associated conformational changes are missing from our current understanding. Notably, the two different substrate translocation mechanisms by $26 \mathrm{~S}$ and 20 proteasomes resulted in different peptide product outcomes despite the same catalytic core and potential endopeptidase cleavages by these two proteasome types [49].

\section{Peptide Generation by the 20S Proteasome}

Proteolysis of a substrate polypeptide inside the self-compartmentalized catalytic chamber of the $20 \mathrm{~S}$ proteasome is highly regulated and modulated by the upstream regulatory mechanism. Under typical physiological conditions, both $20 \mathrm{~S}$ and $26 \mathrm{~S}$ proteasomes cleave protein substrates into small peptides ranging between 3 and 23 amino acids in length $[118,119]$. It is likely that proteasomes also liberate free amino acids, though fewer efforts have been made at documenting free amino acids among proteasome products. Mostly the proteolytic process is processive so that a protein is hydrolyzed within the catalytic chamber to the final products before the next substrate enters; hence, the pattern of peptides generated from a specific protein is relatively stable over time $[119,120]$. In the catalytic chamber of the $20 \mathrm{SCP}$, each of the three catalytic $\beta$-subunits $(\beta 1, \beta 2$ and $\beta 5$ ) preferentially cleaves after specific amino acids: $\beta 1$ cleaves after acidic or small hydrophobic amino acids, $\beta 2$ cuts after basic or small hydrophobic amino acids, while $\beta 5$ hydrolyzes the peptide bond after hydrophobic residues whether bulky or not [110]. However, the rules that govern the cleavage rate and specificity of the same peptide bond can be significantly altered upon attachment of a 195 regulatory particle. An interesting feature of proteasome-dependent proteolysis is that the $20 \mathrm{~S}$ and the $26 \mathrm{~S}$ proteasomes generate different patterns of cleavage products [121], indicating that the distal 19S RP affects the behavior of the 20S CP when put into the context of the 26S proteasome. Attachment of proteasome activators not only influences substrate selection, but may also affect product outcome due to allosteric effects on $\beta$-catalytic active sites [118]. For example, both in vitro and in vivo conditions, $20 \mathrm{~S}$ and $26 \mathrm{~S}$ proteasomes generate different peptide products from an identical substrate protein with respect to their types, amount and sizes [49,118,121,122] Interestingly, it has been shown that cells with high $20 \mathrm{~S}$ proteasome levels, as occurs under hypoxia or human cardiomyopathies, generate elevated amounts of ubiquitin-derived peptides [49], suggesting that some of the ubiquitin tag is proteolyzed along with the 
conjugated substrate. Similar to 19S RP, the presence of alternative caps (PA28 or PA200) on the 20S CP affect the product outcome from the same substrates [123]. Furthermore, the CP contains other "noncatalytic" sites to which additional factors can bind and alter cleavage sites or product composition [124].

It has been reported that free $20 \mathrm{~S}$ proteasomes generate longer peptides than do $26 \mathrm{~S}$ proteasomes $[49,118,121]$ suggesting the gating mechanism differs in both proteasome species. The majority of peptides generated by the $26 \mathrm{~S}$ proteasome contain less than eight amino acids. A fraction of the peptides that are 8-10 amino acids in length can be transported through the ER and presented to the immune system by MHC class I [125,126]. An increase in average peptide product length by shifting proteasome population from $26 \mathrm{~S}$ to $20 \mathrm{~S}$ proteasomes could increase the efficiency of antigen presentation and, by extension, the efficiency of combating viral infection. Understanding the precise rules regulating the makeup of peptides generated by different proteasome species could have far-reaching consequences on predicting immunogenic peptides "hidden" within viral or tumorigenic proteins. Generally, the peptide products are short lived and most of these peptides are likely to be rapidly hydrolyzed by downstream proteases and aminopeptidases. However, some peptides persist in the intracellular peptide pool [127,128]. Apart from the known immunogenic function, these intracellular peptides generated by proteasomes may have the potential to modulate other prospective signaling pathways [129]. Hence, the diverse peptide products from different proteasome species would have high propensity to modulate cellular signaling pathways under various physiological conditions; this, however, needs further investigation.

\section{Concluding Remarks}

Proteasomes are the major intracellular proteases for regulated protein degradation. Most cellular proteins can end up as proteasome substrates either in a regulated manner upon specific molecular cues, or nonspecifically if damaged or misfolded. Finding both the tightly regulated $26 \mathrm{~S}$ proteasome and the simpler free $20 \mathrm{~S}$ complex side-by-side in most eukaryotic cells implies that each may have independent roles in protein homeostasis. Although the $20 \mathrm{~S}$ complex is a less regulated proteasome than the $26 \mathrm{~S}$ holoenzyme and limited to unstructured polypeptides, its levels increase under various human pathologies, suggesting that a proper proteasome ratio may be important for overall protein homeostasis. Overall, $20 \mathrm{~S}$ proteasomes appear to play an emergency role contributing survival benefits to cells under physiological stress.

The signals that target substrates for degradation are distinct for $26 \mathrm{~S}$ and $20 \mathrm{~S}$ proteasomes. While ubiquitination is the major criterion for substrate targeting to the 26S, an unstructured stretch is required for substrate proteolysis by the $20 \mathrm{~S}$ proteasome. In principle, an unstructured stretch could engage at both proteasomes; however, specific ubiquitintriggered conformational changes render $26 \mathrm{~S}$ proteasomes particularly appropriate for ubiquitin-dependent degradation. Likewise, unstructured polypeptides may induce conformational changes to $20 S$ proteasomes for their own degradation. By implication, the substrate repertoire of the two proteasomes is not fully overlapping, which is intriguing since the two proteases have identical catalytic active sites in their cores.

Precise knowledge of how 205 proteasomes work as molecular machines is essential to clarify how they prioritize their substrates in the cell. The current knowledge of $20 \mathrm{~S}$ proteasomes' structural features provides partial information about how these complexes recognize substrates and process them. However, further dissection of $20 \mathrm{~S}$ proteasome mechanisms awaits single-particle analysis with its appropriate substrates, which will unravel the $20 S$ proteasome in action. Additionally, describing the regulatory role of auxiliary factors, proteasome-interacting proteins, post-translational modifications, and cellular and physiological conditions will complete our understanding of 205 proteasome function. Developing approaches to study proteasomes in living cells will clarify how different proteasome species (20S and 26S) contribute to overall intracellular proteolysis. 
The resulting information will aid strategies for the targeted inhibition or modulation of proteasome activities.

Author Contributions: Both authors (I.S. and M.H.G.) wrote the article. All authors have read and agreed to the published version of the manuscript.

Funding: Research in the Glickman lab is supported in part by an Israel Science foundation grant (755/19); NSFC-ISF (2512/18), NSF-BSF (2017727). IS received funding from MSCA-IF Horizon-2020 (748804). MHG is the Israel Isaac and Natalia Kudish Academic Chair.

Conflicts of Interest: The authors declare no conflict of interest.

\section{References}

1. Bajorek, M.; Finley, D.; Glickman, M.H. Proteasome disassembly and downregulation is correlated with viability during stationary phase. Curr. Biol. 2003, 13, 1140-1144. [CrossRef]

2. Livnat-Levanon, N.; Kevei, E.; Kleifeld, O.; Krutauz, D.; Segref, A.; Rinaldi, T.; Erpapazoglou, Z.; Cohen, M.; Reis, N.; Hoppe, T.; et al. Reversible 26S proteasome disassembly upon mitochondrial stress. Cell Rep. 2014, 7, 1371-1380. [CrossRef] [PubMed]

3. Fabre, B.; Lambour, T.; Garrigues, L.; Ducoux-Petit, M.; Amalric, F.; Monsarrat, B.; Burlet-Schiltz, O.; Bousquet-Dubouch, M.P. Label-free quantitative proteomics reveals the dynamics of proteasome complexes composition and stoichiometry in a wide range of human cell lines. J. Proteome Res. 2014, 13, 3027-3037. [CrossRef] [PubMed]

4. Lupas, A.; Flanagan, J.M.; Tamura, T.; Baumeister, W. Self-compartmentalizing proteases. Trends Biochem. Sci. 1997, 22, 399-404. [CrossRef]

5. Demasi, M.; da Cunha, F.M. The physiological role of the free 20 s proteasome in protein degradation: A critical review. Biochim. Biophys. Acta Gen. Subj. 2018, 1862, 2948-2954. [CrossRef]

6. Pickering, A.M.; Davies, K.J. Degradation of damaged proteins: The main function of the 20S proteasome. Prog. Mol. Biol. Transl. Sci. 2012, 109, 227-248. [CrossRef]

7. Kumar Deshmukh, F.; Yaffe, D.; Olshina, M.A.; Ben-Nissan, G.; Sharon, M. The Contribution of the 20S Proteasome to Proteostasis. Biomolecules 2019, 9, 190. [CrossRef]

8. Glickman, M.H.; Rubin, D.M.; Coux, O.; Wefes, I.; Pfeifer, G.; Cjeka, Z.; Baumeister, W.; Fried, V.A.; Finley, D. A subcomplex of the proteasome regulatory particle required for ubiquitin-conjugate degradation and related to the COP9-signalosome and eIF3. Cell 1998, 94, 615-623. [CrossRef]

9. Shringarpure, R.; Grune, T.; Mehlhase, J.; Davies, K.J. Ubiquitin conjugation is not required for the degradation of oxidized proteins by proteasome. J. Biol. Chem. 2003, 278, 311-318. [CrossRef]

10. Eytan, E.; Ganoth, D.; Armon, T.; Hershko, A. ATP-dependent incorporation of 20S protease into the 26S complex that degrades proteins conjugated to ubiquitin. Proc. Natl. Acad. Sci. USA 1989, 86, 7751-7755. [CrossRef]

11. Liu, C.W.; Corboy, M.J.; DeMartino, G.N.; Thomas, P.J. Endoproteolytic activity of the proteasome. Science 2003, $299,408-411$. [CrossRef] [PubMed]

12. McGuire, M.J.; DeMartino, G.N. The latent form of macropain (high molecular weight multicatalytic protease) restores ATPdependent proteolysis to soluble extracts of BHK fibroblasts pretreated with anti-macropain antibodies. Biochem. Biophys. Res. Commun. 1989, 160, 911-916. [CrossRef]

13. McGuire, M.J.; McCullough, M.L.; Croall, D.E.; DeMartino, G.N. The high molecular weight multicatalytic proteinase, macropain, exists in a latent form in human erythrocytes. Biochim. Biophys. Acta 1989, 995, 181-186. [CrossRef]

14. Raynes, R.; Pomatto, L.C.; Davies, K.J. Degradation of oxidized proteins by the proteasome: Distinguishing between the 20S, 26S, and immunoproteasome proteolytic pathways. Mol. Aspects Med. 2016, 50, 41-55. [CrossRef]

15. Majumder, P.; Rudack, T.; Beck, F.; Danev, R.; Pfeifer, G.; Nagy, I.; Baumeister, W. Cryo-EM structures of the archaeal PANproteasome reveal an around-the-ring ATPase cycle. Proc. Natl. Acad Sci. USA 2019, 116, 534-539. [CrossRef]

16. Lowe, J.; Stock, D.; Jap, B.; Zwickl, P.; Baumeister, W.; Huber, R. Crystal structure of the 20 S proteasome from the archaeon T. acidophilum at 3.4 A resolution. Science 1995, 268, 533-539. [CrossRef]

17. Maupin-Furlow, J.A.; Humbard, M.A.; Kirkland, P.A.; Li, W.; Reuter, C.J.; Wright, A.J.; Zhou, G. Proteasomes from structure to function: Perspectives from Archaea. Curr. Top. Dev. Biol. 2006, 75, 125-169.

18. Fort, P.; Kajava, A.V.; Delsuc, F.; Coux, O. Evolution of proteasome regulators in eukaryotes. Genome Biol. Evol. 2015, 7, 1363-1379. [CrossRef]

19. Barthelme, D.; Sauer, R.T. Identification of the Cdc48*20S proteasome as an ancient AAA+ proteolytic machine. Science 2012, 337, 843-846. [CrossRef]

20. Groll, M.; Bajorek, M.; Kohler, A.; Moroder, L.; Rubin, D.M.; Huber, R.; Glickman, M.H.; Finley, D. A gated channel into the proteasome core particle. Nat. Struct. Biol. 2000, 7, 1062-1067. [CrossRef]

21. Bajorek, M.; Glickman, M.H. Proteasome regulatory particles: Keepers of the gates. Cell. Mol. Life Sci. 2004, 61, 1579-1588. [PubMed]

22. Choi, W.H.; de Poot, S.A.; Lee, J.H.; Kim, J.H.; Han, D.H.; Kim, Y.K.; Finley, D.; Lee, M.J. Open-gate mutants of the mammalian proteasome show enhanced ubiquitin-conjugate degradation. Nat. Commun. 2016, 7, 10963. [CrossRef] [PubMed] 
23. Rabinovich, E.; Bajorek, M.; Glickman, M.; Bar-Nun, S. Proteasome Channel Opening as a Rate-Limiting Step in the UbiquitinProteasome System. Isr. J. Chem. 2006, 46, 219-224. [CrossRef]

24. Groll, M.; Huber, R. Substrate access and processing by the 20 S proteasome core particle. Int. J. Biochem. Cell Biol. 2003, 35, 606-616. [CrossRef]

25. Myers, N.; Olender, T.; Savidor, A.; Levin, Y.; Reuven, N.; Shaul, Y. The Disordered Landscape of the 20S Proteasome Substrates Reveals Tight Association with Phase Separated Granules. Proteomics 2018, 18, e1800076. [CrossRef]

26. Chondrogianni, N.; Georgila, K.; Kourtis, N.; Tavernarakis, N.; Gonos, E.S. 20 S proteasome activation promotes life span extension and resistance to proteotoxicity in Caenorhabditis elegans. FASEB J. 2015, 29, 611-622. [CrossRef]

27. Arrigo, A.P.; Tanaka, K.; Goldberg, A.L.; Welch, W.J. Identity of the 195 'prosome' particle with the large multifunctional protease complex of mammalian cells (the proteasome). Nature 1988, 331, 192-194. [CrossRef]

28. Shringarpure, R.; Grune, T.; Davies, K.J. Protein oxidation and $20 \mathrm{~S}$ proteasome-dependent proteolysis in mammalian cells. Cell. Mol. Life Sci. 2001, 58, 1442-1450. [CrossRef]

29. Suskiewicz, M.J.; Sussman, J.L.; Silman, I.; Shaul, Y. Context-dependent resistance to proteolysis of intrinsically disordered proteins. Protein Sci. 2011, 20, 1285-1297. [CrossRef]

30. Tonoki, A.; Kuranaga, E.; Tomioka, T.; Hamazaki, J.; Murata, S.; Tanaka, K.; Miura, M. Genetic evidence linking age-dependent attenuation of the 26S proteasome with the aging process. Mol. Cell Biol. 2009, 29, 1095-1106. [CrossRef]

31. Davies, K.J. Degradation of oxidized proteins by the $20 \mathrm{~S}$ proteasome. Biochimie 2001, 83, 301-310. [CrossRef]

32. Chu-Ping, M.; Vu, J.H.; Proske, R.J.; Slaughter, C.A.; DeMartino, G.N. Identification, purification, and characterization of a high molecular weight, ATP-dependent activator (PA700) of the $20 \mathrm{~S}$ proteasome. J. Biol. Chem. 1992, 269, 3539-3547. [CrossRef]

33. Hoffman, L.; Pratt, G.; Rechsteiner, M. Multiple forms of the $20 \mathrm{~S}$ multicatalytic and the $26 \mathrm{~S}$ ubiquitin/ATP-dependent proteases from rabbit reticulocyte lysate. J. Biol. Chem. 1992, 267, 22362-22368. [CrossRef]

34. Tanaka, K. The proteasome: Overview of structure and functions. Proc. Jpn. Acad. Ser. B Phys. Biol. Sci. 2009, 85, 12-36. [CrossRef] [PubMed]

35. Greene, E.R.; Dong, K.C.; Martin, A. Understanding the $26 \mathrm{~S}$ proteasome molecular machine from a structural and conformational dynamics perspective. Curr. Opin. Struct. Biol. 2020, 61, 33-41. [CrossRef] [PubMed]

36. Davis, C.; Spaller, B.L.; Matouschek, A. Mechanisms of substrate recognition by the 26 S proteasome. Curr. Opin. Struct. Biol. 2020, 67, 161-169. [CrossRef] [PubMed]

37. Majumder, P.; Baumeister, W. Proteasomes: Unfoldase-assisted protein degradation machines. Biol. Chem. 2019, 401, 183-199. [CrossRef]

38. Collins, G.A.; Goldberg, A.L. The Logic of the 26S Proteasome. Cell 2017, 169, 792-806. [CrossRef]

39. Mao, Y. Structure, Dynamics and Function of the 26S Proteasome. Sub-Cell. Biochem. 2021, 96, 1-151. [CrossRef]

40. Bard, J.A.M.; Goodall, E.A.; Greene, E.R.; Jonsson, E.; Dong, K.C.; Martin, A. Structure and Function of the 26S Proteasome. Annu. Rev. Biochem. 2018, 87, 697-724. [CrossRef]

41. Cascio, P. PA28alphabeta: The enigmatic magic ring of the proteasome? Biomolecules 2014, 4, 566-584. [CrossRef] [PubMed]

42. Savulescu, A.F.; Glickman, M.H. Proteasome activator 200: The heat is on. Mol. Cell. Proteom. 2011, 10, R110.006890. [CrossRef] [PubMed]

43. Baldin, V.; Militello, M.; Thomas, Y.; Doucet, C.; Fic, W.; Boireau, S.; Jariel-Encontre, I.; Piechaczyk, M.; Bertrand, E.; Tazi, J.; et al. A novel role for PA28gamma-proteasome in nuclear speckle organization and SR protein trafficking. Mol. Biol. Cell. 2008, 19, 1706-1716. [CrossRef] [PubMed]

44. Suzuki, R.; Moriishi, K.; Fukuda, K.; Shirakura, M.; Ishii, K.; Shoji, I.; Wakita, T.; Miyamura, T.; Matsuura, Y.; Suzuki, T. Proteasomal turnover of hepatitis $C$ virus core protein is regulated by two distinct mechanisms: A ubiquitin-dependent mechanism and a ubiquitin-independent but PA28gamma-dependent mechanism. J. Virol. 2009, 83, 2389-2392. [CrossRef]

45. Dubiel, W.; Pratt, G.; Ferrell, K.; Rechsteiner, M. Purification of an 11 S regulator of the multicatalytic protease. J. Biol. Chem. 1992, 267, 22369-22377. [CrossRef]

46. Ma, C.P.; Slaughter, C.A.; DeMartino, G.N. Identification, purification, and characterization of a protein activator (PA28) of the 20 S proteasome (macropain). J. Biol. Chem. 1992, 267, 10515-10523. [CrossRef]

47. Ustrell, V.; Hoffman, L.; Pratt, G.; Rechsteiner, M. PA200, a nuclear proteasome activator involved in DNA repair. EMBO J. 2002, 21, 3516-3525. [CrossRef]

48. Fehlker, M.; Wendler, P.; Lehmann, A.; Enenkel, C. Blm3 is part of nascent proteasomes and is involved in a late stage of nuclear proteasome assembly. EMBO Rep. 2003, 4, 959-963. [CrossRef]

49. Sahu, I.; Mali, S.M.; Sulkshane, P.; Rozenberg, A.; Xu, C.; Morag, R.; Sahoo, M.P.; Singh, S.K.; Ding, Z.; Wang, Y.; et al. Signature activities of $20 S$ proteasome include degradation of the ubiquitin-tag with the protein under hypoxia. bioRxiv 2019. [CrossRef]

50. Armon, T.; Ganoth, D.; Hershko, A. Assembly of the $26 \mathrm{~S}$ complex that degrades proteins ligated to ubiquitin is accompanied by the formation of ATPase activity. J. Biol. Chem. 1990, 265, 20723-20726. [CrossRef]

51. Tsvetkov, P.; Mendillo, M.L.; Zhao, J.; Carette, J.E.; Merrill, P.H.; Cikes, D.; Varadarajan, M.; van Diemen, F.R.; Penninger, J.M.; Goldberg, A.L.; et al. Compromising the 19S proteasome complex protects cells from reduced flux through the proteasome. eLife 2015, 4. [CrossRef] [PubMed] 
52. Hendil, K.B.; Kriegenburg, F.; Tanaka, K.; Murata, S.; Lauridsen, A.M.; Johnsen, A.H.; Hartmann-Petersen, R. The 20S proteasome as an assembly platform for the $19 \mathrm{~S}$ regulatory complex. J. Mol. Biol. 2009, 394, 320-328. [CrossRef] [PubMed]

53. Sahara, K.; Kogleck, L.; Yashiroda, H.; Murata, S. The mechanism for molecular assembly of the proteasome. Adv. Biol. Regul. 2014, 54, 51-58. [CrossRef] [PubMed]

54. Tomko, R.J., Jr.; Hochstrasser, M. Molecular architecture and assembly of the eukaryotic proteasome. Annu. Rev. Biochem. 2013, 82, 415-445. [CrossRef] [PubMed]

55. Njomen, E.; Osmulski, P.A.; Jones, C.L.; Gaczynska, M.; Tepe, J.J. Small Molecule Modulation of Proteasome Assembly. Biochemistry 2018, 57, 4214-4224. [CrossRef]

56. Jung, T.; Grune, T. The proteasome and its role in the degradation of oxidized proteins. IUBMB Life 2008, 60, 743-752. [CrossRef]

57. Hohn, T.J.; Grune, T. The proteasome and the degradation of oxidized proteins: Part III-Redox regulation of the proteasomal system. Redox Biol. 2014, 2, 388-394. [CrossRef]

58. Mayor, T.; Sharon, M.; Glickman, M.H. Tuning the proteasome to brighten the end of the journey. Am. J. Physiol. Cell Physiol. 2016, 311, C793-C804. [CrossRef]

59. Tsvetkov, P.; Myers, N.; Moscovitz, O.; Sharon, M.; Prilusky, J.; Shaul, Y. Thermo-resistant intrinsically disordered proteins are efficient 20S proteasome substrates. Mol. Biosyst. 2012, 8, 368-373. [CrossRef]

60. Kurepa, J.; Smalle, J.A. To misfold or to lose structure?: Detection and degradation of oxidized proteins by the $20 \mathrm{~S}$ proteasome. Plant Signal. Behav. 2008, 3, 386-388. [CrossRef]

61. Jung, T.; Hohn, A.; Grune, T. The proteasome and the degradation of oxidized proteins: Part II - protein oxidation and proteasomal degradation. Redox Biol. 2014, 2, 99-104. [CrossRef] [PubMed]

62. Enenkel, C. The paradox of proteasome granules. Curr. Genet. 2018, 64, 137-140. [CrossRef] [PubMed]

63. Marshall, R.S.; Vierstra, R.D. Proteasome storage granules protect proteasomes from autophagic degradation upon carbon starvation. eLife 2018, 7. [CrossRef] [PubMed]

64. Peters, L.Z.; Hazan, R.; Breker, M.; Schuldiner, M.; Ben-Aroya, S. Formation and dissociation of proteasome storage granules are regulated by cytosolic pH. J. Cell Biol. 2013, 201, 663-671. [CrossRef] [PubMed]

65. Wang, X.; Yen, J.; Kaiser, P.; Huang, L. Regulation of the 26 S proteasome complex during oxidative stress. Sci. Signal. 2010, 3, ra88. [CrossRef] [PubMed]

66. Besche, H.C.; Sha, Z.; Kukushkin, N.V.; Peth, A.; Hock, E.M.; Kim, W.; Gygi, S.; Gutierrez, J.A.; Liao, H.; Dick, L.; et al. Autoubiquitination of the 26S Proteasome on Rpn13 Regulates Breakdown of Ubiquitin Conjugates. EMBO J. 2014, 33, 1159-1176. [CrossRef] [PubMed]

67. Marshall, R.S.; Li, F.; Gemperline, D.C.; Book, A.J.; Vierstra, R.D. Autophagic Degradation of the 26S Proteasome Is Mediated by the Dual ATG8/Ubiquitin Receptor RPN10 in Arabidopsis. Mol. Cell 2015, 58, 1053-1066. [CrossRef]

68. Wen, X.; Klionsky, D.J. The proteasome subunit RPN10 functions as a specific receptor for degradation of the 26S proteasome by macroautophagy in Arabidopsis. Autophagy 2016, 12, 905-906. [CrossRef]

69. Cohen-Kaplan, V.; Livneh, I.; Avni, N.; Fabre, B.; Ziv, T.; Kwon, Y.T.; Ciechanover, A. p62- and ubiquitin-dependent stress-induced autophagy of the mammalian 26S proteasome. Proc. Natl. Acad. Sci. USA 2016, 113, E7490-E7499. [CrossRef]

70. Reinheckel, T.; Sitte, N.; Ullrich, O.; Kuckelkorn, U.; Davies, K.J.; Grune, T. Comparative resistance of the 20S and 26S proteasome to oxidative stress. Biochem. J. 1998, 335 (Pt 3), 637-642. [CrossRef]

71. Okonko, D.O.; Shah, A.M. Heart failure: Mitochondrial dysfunction and oxidative stress in CHF. Nat. Rev. Cardiol. 2015, 12, 6-8. [CrossRef] [PubMed]

72. Day, S.M.; Divald, A.; Wang, P.; Davis, F.; Bartolone, S.; Jones, R.; Powell, S.R. Impaired assembly and post-translational regulation of 26S proteasome in human end-stage heart failure. Circ. Heart Fail. 2013, 6, 544-549. [CrossRef] [PubMed]

73. Predmore, J.M.; Wang, P.; Davis, F.; Bartolone, S.; Westfall, M.V.; Dyke, D.B.; Pagani, F.; Powell, S.R.; Day, S.M. Ubiquitin proteasome dysfunction in human hypertrophic and dilated cardiomyopathies. Circulation 2010, 121, 997-1004. [CrossRef] [PubMed]

74. Kobayashi, A.; Waku, T. New addiction to the NRF2-related factor NRF3 in cancer cells: Ubiquitin-independent proteolysis through the 20S proteasome. Cancer Sci. 2020, 111, 6-14. [CrossRef] [PubMed]

75. Dwivedi, V.; Yaniv, K.; Sharon, M. Beyond cells: The extracellular circulating 20S proteasomes. Biochim. Biophys. Acta Mol. Basis Dis. 2020, 1867, 166041. [CrossRef]

76. Groll, M.; Ditzel, L.; Lowe, J.; Stock, D.; Bochtler, M.; Bartunik, H.D.; Huber, R. Structure of $20 \mathrm{~S}$ proteasome from yeast at 2.4 A resolution. Nature 1997, 386, 463-471. [CrossRef]

77. Groll, M.; Nazif, T.; Huber, R.; Bogyo, M. Probing structural determinants distal to the site of hydrolysis that control substrate specificity of the $20 \mathrm{~S}$ proteasome. Chem. Biol. 2002, 9, 655-662. [CrossRef]

78. Wenzel, T.; Baumeister, W. Conformational constraints in protein degradation by the 20 S proteasome. Nat. Struct. Biol. 1995, 2, 199-204. [CrossRef]

79. Osmulski, P.A.; Gaczynska, M. Nanoenzymology of the $20 \mathrm{~S}$ proteasome: Proteasomal actions are controlled by the allosteric transition. Biochemistry 2002, 41, 7047-7053. [CrossRef]

80. Grune, T.; Merker, K.; Sandig, G.; Davies, K.J. Selective degradation of oxidatively modified protein substrates by the proteasome. Biochem. Biophys. Res. Commun. 2003, 305, 709-718. [CrossRef] 
81. Grune, T.; Botzen, D.; Engels, M.; Voss, P.; Kaiser, B.; Jung, T.; Grimm, S.; Ermak, G.; Davies, K.J. Tau protein degradation is catalyzed by the ATP/ubiquitin-independent $20 S$ proteasome under normal cell conditions. Arch Biochem. Biophys. 2010, 500, 181-188. [CrossRef] [PubMed]

82. Pickering, A.M.; Staab, T.A.; Tower, J.; Sieburth, D.; Davies, K.J. A conserved role for the $20 \mathrm{~S}$ proteasome and Nrf2 transcription factor in oxidative stress adaptation in mammals, Caenorhabditis elegans and Drosophila melanogaster. J. Exp. Biol. 2013, 216, 543-553. [CrossRef] [PubMed]

83. Touitou, R.; Richardson, J.; Bose, S.; Nakanishi, M.; Rivett, J.; Allday, M.J. A degradation signal located in the C-terminus of p21WAF1/CIP1 is a binding site for the C8 alpha-subunit of the 20S proteasome. EMBO J. 2001, 20, 2367-2375. [CrossRef] [PubMed]

84. Ruff, K.M. Predicting Conformational Properties of Intrinsically Disordered Proteins from Sequence. Methods Mol. Biol. 2020, 2141, 347-389. [CrossRef] [PubMed]

85. Tsvetkov, P.; Reuven, N.; Shaul, Y. The nanny model for IDPs. Nat. Chem. Biol. 2009, 5, 778-781. [CrossRef]

86. Demasi, M.; Hand, A.; Ohara, E.; Oliveira, C.L.; Bicev, R.N.; Bertoncini, C.A.; Netto, L.E. 20 S proteasome activity is modified via S-glutathionylation based on intracellular redox status of the yeast Saccharomyces cerevisiae: Implications for the degradation of oxidized proteins. Arch Biochem. Biophys. 2014, 557, 65-71. [CrossRef] [PubMed]

87. Demasi, M.; Netto, L.E.; Silva, G.M.; Hand, A.; de Oliveira, C.L.; Bicev, R.N.; Gozzo, F.; Barros, M.H.; Leme, J.M.; Ohara, E. Redox regulation of the proteasome via S-glutathionylation. Redox Biol. 2014, 2, 44-51. [CrossRef]

88. Ng, A.H.; Fang, N.N.; Comyn, S.A.; Gsponer, J.; Mayor, T. System-wide analysis reveals intrinsically disordered proteins are prone to ubiquitylation after misfolding stress. Mol. Cell Proteom. 2013, 12, 2456-2467. [CrossRef]

89. Arendt, C.S.; Hochstrasser, M. Identification of the yeast $20 S$ proteasome catalytic centers and subunit interactions required for active-site formation. Proc. Natl. Acad. Sci. USA 1997, 94, 7156-7161. [CrossRef]

90. Groll, M.; Heinemeyer, W.; Jager, S.; Ullrich, T.; Bochtler, M.; Wolf, D.H.; Huber, R. The catalytic sites of 20S proteasomes and their role in subunit maturation: A mutational and crystallographic study. Proc. Nat. Acad. Sci. USA 1999, 96, 10976-10983. [CrossRef]

91. Huber, E.M.; Heinemeyer, W.; Li, X.; Arendt, C.S.; Hochstrasser, M.; Groll, M. A unified mechanism for proteolysis and autocatalytic activation in the $20 \mathrm{~S}$ proteasome. Nat. Commun. 2016, 7, 10900. [CrossRef] [PubMed]

92. Volker, C.; Lupas, A. Molecular Evolution of Proteasomes. In Current Topics in Microbiology and Immunology; Zwickl, P., Baumeister, W., Eds.; Springer-Verlag: Berlin/Heidelberg, Germany, 2002; Volume 268, pp. 1-22.

93. da Fonseca, P.C.; Morris, E.P. Structure of the human 26S proteasome: Subunit radial displacements open the gate into the proteolytic core. J. Biol. Chem. 2008, 283, 23305-23314. [CrossRef] [PubMed]

94. Rabl, J.; Smith, D.M.; Yu, Y.; Chang, S.C.; Goldberg, A.L.; Cheng, Y. Mechanism of gate opening in the $20 \mathrm{~S}$ proteasome by the proteasomal ATPases. Mol. Cell 2008, 30, 360-368. [CrossRef] [PubMed]

95. Köhler, A.; Cascio, P.; Leggett, D.S.; Woo, K.M.; Goldberg, A.L.; Finley, D. The Axial Channel of the Proteasome Core Particle Is Gated by the Rpt2 ATPase and Controls Both Substrate Entry and Product Release. Mol. Cell 2001, 7, 1143-1152. [CrossRef]

96. Sadre-Bazzaz, K.; Whitby, F.G.; Robinson, H.; Formosa, T.; Hill, C.P. Structure of a Blm10 complex reveals common mechanisms for proteasome binding and gate opening. Mol. Cell 2010, 37, 728-735. [CrossRef]

97. Osmulski, P.A.; Hochstrasser, M.; Gaczynska, M. A tetrahedral transition state at the active sites of the 20S proteasome is coupled to opening of the alpha-ring channel. Structure 2009, 17, 1137-1147. [CrossRef]

98. Dong, Y.; Zhang, S.; Wu, Z.; Li, X.; Wang, W.L.; Zhu, Y.; Stoilova-McPhie, S.; Lu, Y.; Finley, D.; Mao, Y. Cryo-EM structures and dynamics of substrate-engaged human $26 \mathrm{~S}$ proteasome. Nature 2019, 565, 49-55. [CrossRef]

99. Sdek, P.; Ying, H.; Chang, D.L.; Qiu, W.; Zheng, H.; Touitou, R.; Allday, M.J.; Xiao, Z.X. MDM2 promotes proteasome-dependent ubiquitin-independent degradation of retinoblastoma protein. Mol. Cell 2005, 20, 699-708. [CrossRef]

100. Giono, L.E.; Resnick-Silverman, L.; Carvajal, L.A.; St Clair, S.; Manfredi, J.J. Mdm2 promotes Cdc25C protein degradation and delays cell cycle progression through the G2/M phase. Oncogene 2017, 36, 6762-6773. [CrossRef]

101. Barthelme, D.; Chen, J.Z.; Grabenstatter, J.; Baker, T.A.; Sauer, R.T. Architecture and assembly of the archaeal Cdc48*20S proteasome. Proc. Natl. Acad. Sci. USA 2014, 111, E1687-E1694. [CrossRef]

102. Gillette, T.G.; Kumar, B.; Thompson, D.; Slaughter, C.A.; DeMartino, G.N. Differential roles of the COOH termini of AAA subunits of PA700 (19 S regulator) in asymmetric assembly and activation of the 26 S proteasome. J. Biol. Chem. 2008, 283, 31813-31822. [CrossRef] [PubMed]

103. Kumar, B.; Kim, Y.C.; DeMartino, G.N. The C terminus of Rpt3, an ATPase subunit of PA700 (19 S) regulatory complex, is essential for $26 \mathrm{~S}$ proteasome assembly but not for activation. J. Biol. Chem. 2010, 285, 39523-39535. [CrossRef] [PubMed]

104. Smith, D.M.; Chang, S.C.; Park, S.; Finley, D.; Cheng, Y.; Goldberg, A.L. Docking of the proteasomal ATPases' carboxyl termini in the $20 \mathrm{~S}$ proteasome's alpha ring opens the gate for substrate entry. Mol. Cell. 2007, 27, 731-744. [CrossRef] [PubMed]

105. Toste Rego, A.; da Fonseca, P.C.A. Characterization of Fully Recombinant Human 20S and 20S-PA200 Proteasome Complexes. Mol. Cell. 2019, 76, 138-147.e135. [CrossRef] [PubMed]

106. Kisselev, A.F.; Kaganovich, D.; Goldberg, A.L. Binding of hydrophobic peptides to several non-catalytic sites promotes peptide hydrolysis by all active sites of $20 \mathrm{~S}$ proteasomes. Evidence for peptide-induced channel opening in the alpha-rings. J. Biol. Chem. 2002, 277, 22260-22270. [CrossRef]

107. Gaczynska, M.; Osmulski, P.A. Harnessing proteasome dynamics and allostery in drug design. Antioxid. Redox Signal. 2014, 21, 2286-2301. [CrossRef] 
108. Silva, G.M.; Netto, L.; Simoes, V.; Santos, L.F.; Gozzo, F.C.; Demasi, M.A.; Oliveira, C.L.; Bicev, R.N.; Klitzke, C.F.; Sogayar, M.C.; et al. Redox Control of 20s Proteasome Gating. Antioxid. Redox Signal. 2012. [CrossRef]

109. Chen, P.; Hochstrasser, M. Autocatalytic subunit processing couples active site formation in the $20 \mathrm{~S}$ proteasome to completion of assembly. Cell 1996, 86, 961-972. [CrossRef]

110. Dick, T.P.; Nussbaum, A.K.; Deeg, M.; Heinemeyer, W.; Groll, M.; Schirle, M.; Keilholz, W.; Stevanovic, S.; Wolf, D.H.; Huber, R.; et al. Contribution of proteasomal beta-subunits to the cleavage of peptide substrates analyzed with yeast mutants. J. Biol. Chem. 1998, 273, 25637-25646. [CrossRef]

111. Heinemeyer, W.; Fischer, M.; Krimmer, T.; Stachon, U.; Wolf, D.H. The active sites of the eukaryotic $20 \mathrm{~S}$ proteasome and their involvement in subunit precursor processing. J. Biol. Chem. 1997, 272, 25200-25209. [CrossRef]

112. Budenholzer, L.; Cheng, C.L.; Li, Y.; Hochstrasser, M. Proteasome Structure and Assembly. J. Mol. Biol. 2017, 429, 3500-3524. [CrossRef] [PubMed]

113. Gu, Z.C.; Enenkel, C. Proteasome assembly. Cell. Mol. Life Sci. 2014, 71, 4729-4745. [CrossRef] [PubMed]

114. Hutschenreiter, S.; Tinazli, A.; Model, K.; Tampe, R. Two-substrate association with the $20 \mathrm{~S}$ proteasome at single-molecule level. EMBO J. 2004, 23, 2488-2497. [CrossRef] [PubMed]

115. Rennella, E.; Huang, R.; Yu, Z.; Kay, L.E. Exploring long-range cooperativity in the 20 S proteasome core particle from Thermoplasma acidophilum using methyl-TROSY-based NMR. Proc. Natl. Acad. Sci. USA 2020, 117, 5298-5309. [CrossRef] [PubMed]

116. de la Pena, A.H.; Goodall, E.A.; Gates, S.N.; Lander, G.C.; Martin, A. Substrate-engaged 26S proteasome structures reveal mechanisms for ATP-hydrolysis-driven translocation. Science 2018, 362. [CrossRef] [PubMed]

117. Luan, B.; Huynh, T.; Li, J.; Zhou, R. Nanomechanics of Protein Unfolding Outside a Generic Nanopore. ACS Nano 2016, 10, 317-323. [CrossRef] [PubMed]

118. Kisselev, A.F.; Akopian, T.N.; Woo, K.M.; Goldberg, A.L. The sizes of peptides generated from protein by mammalian 26 and 20 S proteasomes. Implications for understanding the degradative mechanism and antigen presentation. J. Biol. Chem. 1999, 274, 3363-3371. [CrossRef]

119. Nussbaum, A.K.; Dick, T.P.; Keilholz, W.; Schirle, M.; Stevanovic, S.; Dietz, K.; Heinemeyer, W.; Groll, M.; Wolf, D.H.; Huber, R.; et al. Cleavage motifs of the yeast $20 \mathrm{~S}$ proteasome beta subunits deduced from digests of enolase 1. Proc. Natl. Acad. Sci. USA 1998, 95, 12504-12509. [CrossRef]

120. Kisselev, A.F.; Akopian, T.N.; Goldberg, A.L. Range of sizes of peptide products generated during degradation of different proteins by archaeal proteasomes. J. Biol. Chem. 1998, 273, 1982-1989. [CrossRef]

121. Emmerich, N.P.; Nussbaum, A.K.; Stevanovic, S.; Priemer, M.; Toes, R.E.; Rammensee, H.G.; Schild, H. The human 26 S and $20 \mathrm{~S}$ proteasomes generate overlapping but different sets of peptide fragments from a model protein substrate. J. Biol. Chem. 2000, 275, 21140-21148. [CrossRef]

122. Toes, R.E.; Nussbaum, A.K.; Degermann, S.; Schirle, M.; Emmerich, N.P.; Kraft, R.; Zwinderman, A.; Dick, T.P.; Muller, J.; Schonfisch, B.; et al. Discrete cleavage motifs of constitutive and immunoproteasomes: Quantitive analysis of cleavage products. J. Exp. Med. 2001, 194, 1-12. [CrossRef] [PubMed]

123. Raule, M.; Cerruti, F.; Benaroudj, N.; Migotti, R.; Kikuchi, J.; Bachi, A.; Navon, A.; Dittmar, G.; Cascio, P. PA28alphabeta reduces size and increases hydrophilicity of 20S immunoproteasome peptide products. Chem. Biol. 2014, 21, 470-480. [CrossRef] [PubMed]

124. Schmidtke, G.; Emch, S.; Groettrup, M.; Holzhutter, H.G. Evidence for the existence of a non-catalytic modifier site of peptide hydrolysis by the $20 \mathrm{~S}$ proteasome. J. Biol. Chem. 2000, 275, 22056-22063. [CrossRef] [PubMed]

125. Glickman, M.H. Getting in and out of the proteasome. Semin. Cell Dev. Biol. 2000, 11, 149-158. [CrossRef] [PubMed]

126. Rechsteiner, M.; Realini, C.; Ustrell, V. The proteasome activator 11 S REG (PA28) and class I antigen presentation. Biochem. J. 2000, 345 Pt 1, 1-15. [CrossRef]

127. Dasgupta, S.; Castro, L.M.; Dulman, R.; Yang, C.; Schmidt, M.; Ferro, E.S.; Fricker, L.D. Proteasome inhibitors alter levels of intracellular peptides in HEK293T and SH-SY5Y cells. PLoS One 2014, 9, e103604. [CrossRef]

128. Dasgupta, S.; Yang, C.; Castro, L.M.; Tashima, A.K.; Ferro, E.S.; Moir, R.D.; Willis, I.M.; Fricker, L.D. Analysis of the Yeast Peptidome and Comparison with the Human Peptidome. PLoS ONE 2016, 11, e0163312. [CrossRef]

129. de Araujo, C.B.; Heimann, A.S.; Remer, R.A.; Russo, L.C.; Colquhoun, A.; Forti, F.L.; Ferro, E.S. Intracellular Peptides in Cell Biology and Pharmacology. Biomolecules 2019, 9, 150. [CrossRef] 